\title{
ELK3 wt Allele
}

National Cancer Institute

\section{Source}

National Cancer Institute. ELK3 wt Allele. NCI Thesaurus. Code C52541.

Human ELK3 wild-type allele is located in the vicinity of $12 \mathrm{q} 23$ and is approximately $73 \mathrm{~kb}$ in length. This allele, which encodes ETS domain-containing protein Elk-3, plays a role in the modulation of transcription by RNA polymerase II. 